\title{
Recurrent Skin Squamous Cell Carcinoma
}

National Cancer Institute

\section{Source}

National Cancer Institute. Recurrent Skin Squamous Cell Carcinoma. NCI Thesaurus.

Code C143012.

The reemergence of squamous cell carcinoma of the skin after a period of remission. 